\title{
Iressa's fall from grace points to need for better clinical trials
}

The much-hyped cancer drug Iressa is showing worrying signs that it may not live up to its promise: clinical trial results released in December showed the drug does not prolong survival in patients with non-small cell lung cancer. Some scientists say the disappointing results underscore the need for clinical trials designed specifically to test targeted therapies.

In January, Iressa's manufacturer AstraZeneca withdrew the application for its approval in Europe, saying results from the clinical study made it unlikely that it would meet approval requirements. The announcement surprised some oncologists, who say Iressa and similar drugs have a promising future in a small group of patients.

"I'd be disappointed if [AstraZeneca] folds up its tent and goes home," says David Johnson, president of the American Society of Clinical Oncology. An AstraZeneca spokesperson says the company will continue to sell the drug but will not actively market it. AstraZeneca also plans further analysis on subpopulations from the clinical trial.

Earlier studies had showed that Iressa can significantly shrink tumors in ten percent of lung cancer patients, many of whom have a mutation in an enzyme targeted by the drug (Science 304, 1497-1500; 2004, N. Engl. J. Med. 350, 2129$2139 ; 2004)$. This mutation is most common in women, Asians and in those with adenocarcinomas, the most common type of lung cancer.

The US Food and Drug Administration (FDA) gave Iressa accelerated approval in May 2003, under a program that allows the agency to revoke the decision if postmarketing clinical trials don't support the initial results. The FDA says it will review details of the December study to see if a change in status is warranted.

The FDA approved a similar drug, Genentech's Tarceva, in November 2004. Both drugs are thought to inhibit epidermal growth factor receptors involved in cancer cell growth. In clinical trials, Tarceva was shown to increase survival in cancer patients by two months.

"Most doctors believe there is no significant difference between the two," says Jennifer Temel, a clinician at Massachusetts General Hospital. Temel attributes the disparate outcomes to small differences in study design.
"We all have a handful of patients who have survived years because of [Iressa]," she says.

Iressa was heralded as key example of the potential of targeted cancer therapies. But its power may have been lost in the recent largescale trial. The 1,700 participants were part of the general patient population, rather than the subgroup most likely to respond to the drug.

Johnson says clinical trials must be designed to clarify the true potential of the growing number of targeted therapies. He and others are trying to change the way such drugs are evaluated. One solution is to better understand how a drug acts and why some patients respond before beginning large-scale trials.

Bruce E. Johnson, director of thoracic oncology at the Dana-Farber Cancer Institute says that, despite the setbacks, Iressa might prove more effective than chemotherapy in that key group of patients, and hopes similar drugs will continue to be developed. "The more agents we have to test and compare, the more opportunities to tailor-make treatments for specific individuals."

Emily Singer, Boston

\section{Logistical hurdles slow California's lofty stem cell scheme}

\section{California's new Institute for Regenerative} Medicine is forging ahead with schemes to fund scientists for human embryonic stem cell research, possibly as early as May. But a rocky start for the institute's oversight committee, which met for the first time in December, along with a laundry list of standards and procedures to resolve, may conspire against such ambitious plans.

Voted in by California's citizens in November, the institute is intended to close the funding gap left by federal restrictions on the use of US federal dollars for stem cell work (Nat. Med. 10, 882; 2004). It is charged with distributing research and facilities grants totaling about $\$ 300$ million each year for the next ten years.

But in early December, state senator Deborah Ortiz, who had been a strong supporter of the initiative, introduced legislation to close what she said were gaps in accountability created by the proposition. Among the changes proposed in the bill are patient protection guidelines and making public the deliberations of the institute's working groups. The bill could be put to a vote in the next few months.

Much of the agenda for the meeting on 17 December of the institute's Independent Citizens Oversight Committee (ICOC) was

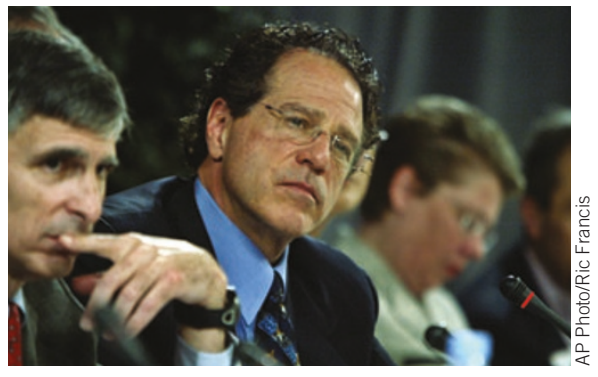

Robert Klein, chair of California's stem cell committee, says it will begin doling out funds by May.

scrapped after watchdog groups complained that the organizers gave inadequate notice of the meeting to the public. The committee instead limited itself to electing its chair and vice chair. Named to these posts were Robert Klein, a real estate developer from Palo Alto and campaign leader for the proposition, and Ed Penhoet, a San Francisco-based biotechnology entrepreneur.

Most of the postponed matters were taken up at a second meeting, held in Los Angeles on 6 January. At that meeting, Klein said he wants the institute to write its first checks to researchers by the end of May. That plan is in keeping with the short deadlines established by the initiative itself, all of which have been met or very nearly met.
But an array of logistical hurdles remain, not least of which is the selection of the 15-member working group of stem cell scientists that will both recommend criteria for successful grants and review the applications that come in. At the January meeting, the ICOC delegated members to begin this process.

Several research institutions_-including those that lack medical centers - have already begun assembling proposals. For example, Robert Tjian, a molecular biologist at the University of California in Berkeley, says the university plans to seek support for work on stem cell differentiation and tissue engineering.

Watchdog groups say they plan to monitor the institute's progress. Some of their concerns have already been resolved. For instance, Klein agreed in January to avoid holding an interest in any biotechnology or real estate company that could benefit from the institute. But critics say other members of the ICOC should also refrain from such affiliations.

Getting such issues settled at the outset is crucial, says Marcy Darnovsky, associate executive director of the Center for Genetics and Society, an Oakland-based advocacy group. "You build in the structure and the rules from the start, and that is what is happening now," she says. Jonathan Knight, San Francisco 